\title{
Fluctuations in Relative Levels of Choline Acetyltransferase mRNA in Different Regions of the Rat Basal Forebrain across the Estrous Cycle: Effects of Estrogen and Progesterone
}

\author{
Robert B. Gibbs \\ Department of Pharmacy and Therapeutics, University of Pittsburgh School of Pharmacy, Pittsburgh, Pennsylvania 15261
}

\begin{abstract}
Quantitative in situ hybridization techniques were used to compare relative cellular levels of choline acetyltransferase (ChAT) mRNA in different regions of the female rat basal forebrain at different stages of the estrous cycle and at different time points after the administration of physiological levels of estrogen and progesterone. Significant fluctuations in relative levels of ChAT mRNA were detected during the course of the estrous cycle. In the medial septum (MS) and striatum, the highest levels of ChAT mRNA were detected on diestrus 1. Fluctuations in the nucleus basalis magnocellularis (NBM) were highly variable, with the highest levels detected on diestrus 2. In ovariectomized animals, significant increases in ChAT mRNA were detected in the MS, NBM, and striatum within 1-3 d after a single administration of estradiol. In addition, the effects of estradiol on ChAT mRNA expression in the NBM and striatum were significantly enhanced
\end{abstract}

by the subsequent administration of progesterone. The magnitude and timing of the effects of steroid replacement were consistent with the magnitude and time course of the fluctuations detected during the course of the estrous cycle. These data demonstrate that estrogen and progesterone can increase basal forebrain levels of ChAT mRNA significantly in specific regions of the rat basal forebrain, that the magnitude and time course of the effects vary between different subpopulations of cholinergic neurons, and that the effects are associated with changes in the functioning of specific basal forebrain cholinergic neurons across the estrous cycle.

Key words: cholinergic neurons; ChAT mRNA; gonadal hormones; Alzheimer's disease; estrous cycle; hormone replacement
Cholinergic neurons in the basal forebrain provide the major source of cholinergic innervation to the hippocampal formation and cortex and play an important role in cortical arousal, attention, and learning and memory processes (for review, see Beninger et al., 1989; Gibbs, 1994). Agents and/or injuries that disrupt basal forebrain cholinergic projections produce significant learning and memory deficits in both animals and humans (Drachman, 1977; Penetar and McDonough, 1983; Aigner and Mishkin, 1986; Dekker et al., 1991). Likcwisc, significant cholincrgic deficits associated with aging and with neurodegenerative diseases such as Alzheimer's disease and Down's syndrome have been described and are thought to contribute to both age- and diseaserelated cognitive decline.

The mechanisms responsible for the decreases in cholinergic function associated with aging and disease are currently unknown. A number of factors that can influence the survival and function of basal forebrain cholinergic neurons have been identified. Most notable are the neurotrophins nerve growth factor (NGF) and brain-derived neurotrophic factor (BDNF), which are produced in the target areas of basal forebrain cholinergic projection neurons (i.e., the hippocampus and cortex) and within subregions of the basal forebrain, and which support and enhance the survival and

\footnotetext{
Received Sept. 12, 1995; revised Nov. 2, 1995; accepted Nov. 7, 1995.

This research was supported by National Institutes of Health Grant RO1 NS28896. I thank Douglas Nelson and Denise Gillen-Caralli for their excellent technical assistance, and I thank Drs. Donghai Wu and Louis Hersh (Department of Biochem istry, University of Kentucky, Lexington, KY) for providing a portion of the rat ChAT gene.

Correspondence should be addressed to Dr. Rohert Gibbs, Lniversity of Pittsburgh School of Pharmacy, 1004 Salk Hall, Pittsburgh, PA 15261.

Copyright (C) 1996 Socicty for Neuroscience $0270-6474 / 96 / 161049-07 \$ 05.00 / 0$
}

function of basal forebrain cholinergic neurons during development and in adulthood (for review, see Gibbs, 1994).

Several recent studies suggest that basal forebrain cholinergic neurons also can be affected by changes in circulating levels of gonadal steroids. In particular, estrogen replacement increases choline acetyltransferase (ChAT) activity (Luine, 1985; Singh et al., 1994) and high-affinity choline uptake (Singh et al., 1994) in the hippocampal formation, cortex, and basal forebrain of ovariectomized femalc rats. Estrogen replacement also increascs the numbers of ChAT-immunoreactive neurons detected in the medial septum (MS) and the vertical limb of the diagonal band of Broca (DBB) (Gibbs and Pfaff, 1992) and increases relative cellular levels of ChAT mRNA within cholinergic neurons located in the MS and nucleus basalis magnocellularis (NBM) (Gibbs et al., 1994). These studies suggest that a loss of gonadal function in women contributes to a decrease in basal forebrain cholinergic function and that this effect may be reversible with appropriate hormone-replacement therapy. This idea is consistent with several recent reports showing beneficial effects of short- and long-term estrogen administration on cognitive performance in women with Alzheimer's disease (Henderson et al., 1994; Ohkura et al., 1994a,b, 1995).

At present, there is very little information regarding how cholinergic neurons located in different regions of the basal forebrain respond to physiological fluctuations in circulating levels of gonadal steroids. In the present study, quantitative in situ hybridization techniques were used to determine whether relative cellular levels of ChAT mRNA in different regions of the rat basal forebrain fluctuate during the course of the estrous cycle. Identical techniques also were used to examine changes in relative levels of ChAT mRNA in ovariectomized animals killed at different 
time points after the administration of physiological levels of estrogen or estrogen plus progesterone. This enabled a comparison between changes observed during the course of the estrous cycle and the magnitude and time course of changes observed in response to acute hormone replacement.

\section{MATERIALS AND METHODS}

Experimental groups. Gonadally intact and ovariectomized female SpragueDawley rats (180-200 gm) were purchased from Charles River Laboratories (Wilmington, MA) and maintained on a $12 \mathrm{hr}$ light $/ 12 \mathrm{hr}$ dark cycle with lights on at 7 A.M. and with food and water available ad libitum. All animals were housed for a minimum of 2 weeks before use. Daily vaginal smears were obtained from gonadally intact animals for a period of 2 weeks to determine the stage of estrous cycle of each animal. These animals then were killed on the morning (9:30-11:00 A.M.) of diestrus 2 $(n=7)$, the morning of proestrus $(n=6)$, the afternoon $(3: 30-5: 00$ P.M. $)$ of proestrus $(n=5)$, the morning of estrus $(n=6)$, or the morning of diestrus $1(n=8)$.

Ovariectomized animals received a single injection of 17 - $\beta$-estradiol (10 $\mu \mathrm{g}$ in $0.1 \mathrm{ml}$ of sesame oil, s.c.; $n=29$ ) at 10 A.M.. Estrogen-treated animals were killed $5 \mathrm{hr}(n=4), 24 \mathrm{hr}(n=5), 53 \mathrm{hr}(n=5)$, or $72 \mathrm{hr}$ $(n=5)$ later. In addition, 10 animals received progesterone $(500 \mu \mathrm{g}$ in 0.1 $\mathrm{ml}$ of sesame oil, s.c.) $48 \mathrm{hr}$ after receiving estrogen and were killed $5 \mathrm{hr}$ $(\mathrm{E} 53+\mathrm{P} ; n=5)$ or $24 \mathrm{hr}(\mathrm{E} 72+\mathrm{P} ; n=5)$ later. Ovariectomized vehicletreated animals $(n=8)$ were used as controls.

Tissue collection. Animals were anesthetized with pentobarbital (50 $\mathrm{mg} / \mathrm{kg}$ ) and then decapitated. The brains were removed, frozen with dry ice, and stored in liquid $\mathrm{N}_{2}$ until sectioning. Trunk blood was collected into $16 \times 125 \mathrm{~mm}^{2}$ glass tubes, placed on ice for $30-60 \mathrm{~min}$, and then centrifuged at $3000 \times g$ for $20 \mathrm{~min}$; the serum was collected and stored at $-20^{\circ} \mathrm{C}$ for the determination of estradiol circulating levels (see below).

Ten-micrometer cryostat sections were cut in the coronal plane through the MS, the DBB, and the NBM. Sections were mounted onto organosilane-treated glass slides (Uhl, 1986), dried on a slide warmer $\left(48^{\circ} \mathrm{C}\right.$ ), and then fixed by immersion in $4 \% \mathrm{p}$-formaldehyde in $0.1 \mathrm{M}$ PBS, pH 7.2, for 5 min. Sections were rinsed with PBS (3 min), dehydrated through a graded series of ethanols $(50,75$, and $95 \%, 1 \mathrm{~min}$ each), and immersed for $10 \mathrm{~min}$ in a solution of $0.25 \%$ acetic anhydride containing $0.1 \mathrm{M}$ triethanolamine, $\mathrm{pH} 8.0$. Sections then were rinsed for $10 \mathrm{~min}$ with $0.2 \times$ SSC ( $2 \times$ SSC: $0.30 \mathrm{M}$ sodium chloride, $0.03 \mathrm{~m}$ sodium citrate), dehydrated through a series of ethanols, and dried in a desiccator. Tissues were frozen at $-70^{\circ} \mathrm{C}$ until use.

In situ hybridization. ChAT mRNA was detected using a single-stranded RNA probe prepared from a $\mathrm{T} 3 / \mathrm{T} 7$ transcription vector containing a highly conserved region (Sacl-HinclI digest, nucleotides 1324-2044) of the rat ChAT gene (Brice et al., 1989) cloned into pBluescript. First, the insert was subcloncd and amplificd with the T3 and T7 promoters intact, using PCR techniques and primers directed against the T3 and T7 promoters. Sense and antisense riboprobes (specific activity, $\sim 2 \times 10^{7} \mathrm{cpm} / \mathrm{pmol}$ ) then were transcribed, using T3 and T7 RNA polymerases with ${ }^{33} \mathrm{P}$-labeled uridine triphosphate (DuPont NEN, Boston, MA) $(-800 \mathrm{Ci} / \mathrm{mmol})$ in the reaction mixture. The probes then were hydrolyzed to an average length of $\sim 300$ bases (Cox et al., 1983). Unincorporated nucleotides were removed by passage through a G-50 Sephadex RNA spin column (Boehringer Mannheim, Indianapolis, IN). Probes then were extracted with phenol/chloroform, precipitated with ethanol, and resuspended in diethylpyrocarbonate-treated water before use.

Matched sections through the MS [corresponding to plates 15-16 in Paxinos and Watson (1986)], the horizontal limb of the diagonal band of Broca (HDB) [corresponding to plates 19-20 in Paxinos and Watson (1986)], the NBM [corresponding to plates 24-25 in Paxinos and Watson (1986)], and the striatum [corresponding to plates 15-16 and 19-20 in Paxinos and Watson (1986)] were selected and thawed in a desiccator at room temperature. Cells in the vertical limb of the DBB were omitted from the analysis because of the possibility for contamination with cells in the HDB (the horizontal limb merges with and is indistinguishable from the vertical limb at levels where the vertical limb is easily distinguished from the MS). Because of the large number of sections involved, sections were divided into experimental runs in which at least one section per animal through a given brain region was exposed to the same antisense probe within each run.

In situ hybridization was performed almost exactly as described previously (Gibbs et al., 1994). Briefly, all sections were covered with prehybridization buffer (Gibbs and Pfaff, 1994) for 2-3 hr and then with hybridization buffer (HB) (Gibbs and Pfaff, 1994) containing ${ }^{33}$ P-labeled sense or antisense probes (0.08-0.1 pmol/section in $40 \mu \mathrm{l}$ of HB). The sense probe was used as a negative control because it is chemically similar to the antisense probe and contains the same percentage GTP/CTP but does not bind with any known species of RNA. Some sections were hybridized with $\mathrm{HB}$ alone (without probe) as an additional negative control.

Hybridization proceeded for $2 \mathrm{~d}$ at $50^{\circ} \mathrm{C}$, after which sections were rinsed with $2 \times, 1 \times$, and $0.5 \times \mathrm{SSC}(15 \mathrm{~min}$ each $)$ and then with $0.1 \times \mathrm{SSC}$ for $2 \mathrm{hr}$. Sections then were treated with ribonuclease A (RNase-A Sigma type X-A: $5.0 \mu \mathrm{g} / \mathrm{ml}$ in $10 \mathrm{~mm}$ Tris, $\mathrm{pH} 8.0,0.5 \mathrm{M} \mathrm{NaCl}$, and $1 \mathrm{~mm}$ EDTA; St. Louis, MO) for $30 \mathrm{~min}$ at $37^{\circ} \mathrm{C}$, rinsed with $\mathrm{RNase}$ buffer $(30 \mathrm{~min}$ at $37^{\circ} \mathrm{C}$ ), and then rinsed with $0.1 \times \mathrm{SSC}$ for $1 \mathrm{hr}$ at $60^{\circ} \mathrm{C}$ followed by $0.1 \times$ SSC at $42^{\circ} \mathrm{C}$ overnight. The next day, sections were treated for 1 min each in $300 \mathrm{~mm}$ ammonium acetate/ethanol diluted $1: 1,3: 7$, and $1: 9$ and, finally, in absolute ethanol. Sections then were dried in a desiccator, dipped in Kodak NTB-3 emulsion ( $44^{\circ} \mathrm{C}$; Rochester, NY), and stored in dry, light-tight boxes at $4^{\circ} \mathrm{C}$ for $8-10 \mathrm{~d}$. Autoradiograms were developed with Kodak D-19 developer, fixed with Kodak fixer, stained with cresyl violet, coverslipped with DePex (Gurr, UK), and examined with a Leitz photomicroscope.

Data analysis. Relative cellular levels of ChAT mRNA were quantified in the MS, HDB, NBM, and striatum as described previously (Gibbs et al., 1994). Cells in the MS were distinguished from cells in the vertical limb of the $\mathrm{DBB}$ by an imaginary line drawn through the anterior commissure. Individually labeled cells were identified using high-power, bright-field microscopy. Only labeled cells with an identifiable nucleus were included in the analysis. The number of pixels covered by reduced silver grains overlying each labeled cell was counted for all labeled cells in each of two sections per region per animal, using a Bioquant true-color image analysis system. In this way, we analyzed $\sim 50-125$ labeled cells per region per animal. Extreme care was taken to ensure that lighting was constant for all sections analyzed within a given series.

Background labeling per unit area was estimated for each region per section by averaging the number of pixels covered by silver grains in 10 fields $\left(30,625 \mathrm{\mu m}^{2} /\right.$ field) in which no labeled cells were detected. Estimates of background labeling in the MS, HDB, and NBM were obtained from 10 "empty" fields (fields in which no labeled cells were detected) across nearby cortex. Estimates of background labeling in the striatum were obtained from 10 empty fields through the striatum. This was possible in the striatum, where labeled cells were widely dispersed. Estimated background was calculated and subtracted from each cell. Only those cells for which the number of overlying pixels exceeded background by 4 SDs were considered labcled and were included in the analysis. All data within an experimental run were transformed to represent percent change from the arihnetic mean of the control group. This was donte so that data from different experimental runs could be combined. For the cycling animals, data were transformed to represent percent change from diestrus 2. All data points from a given region per animal across different experimental runs then were combined and averaged. An unweighted estimate of the average percent change in the number of grains per cell then was calculated for each group.

Statistical analyses were performed using SYSTAT 5.2 for Macintosh (SYSTAT, Evanston, IL). Group means for animals killed at different stages of the estrous cycle were compared using ANOVA. Comparisons of individual pairs of means were made using the Tukey test. Group means for the estrogen-treated and estrogen plus progesterone-treated animals were compared with the ovariectomized controls by using a two-tailed Dunnett test. Preselected contrasts between E53 versus $\mathrm{E} 53+\mathrm{P}$ and belween $\mathrm{E} 72$ versus $\mathrm{E} 72+\mathrm{P}$ also were performed.

Serum estradiol assay. Serum concentrations of estradiol were measured by radioimmunoassay using commercially available kits from Diagnostic Products (Los Angeles, (A). Charcoal-extracted rat serum was used as the diluent for the standard curve. Samples were run in duplicate, and all samples from a given experiment (i.e., from all gonadally intact animals or from all estrogen-treated animals) were run together. The lower level of detectability was $10 \mathrm{pg} / \mathrm{ml}$.

\section{RESULTS}

Radioimmunoassay results are summarized in Table 1. In gonadally intact animals, serum estradiol was detectable on the morning of proestrus and peaked on the afternoon of proestrus at a mean level of $47.9 \pm 8.5 \mathrm{pg} / \mathrm{ml}$. In ovariectomized animals, a single injection of estradiol caused mean serum levels of $53.0 \pm 9.1$ 


\begin{tabular}{lr}
\hline Table 1. Serum estradiol levels $(\mathbf{p g} / \mathbf{m l} \pm$ SEM) \\
\hline Gonadally intact animals \\
Diestrus 2 & $1.5 \pm 1.3$ \\
Proestrus AM & $28.6 \pm 5.6$ \\
Proestrus PM & $47.9 \pm 8.5$ \\
Estrous & $2.2 \pm 1.8$ \\
Diestrus 1 & $3.1 \pm 2.0$ \\
Ovariectomized and hormone-treated animals & \\
Ovx & $0.0 \pm 0.0$ \\
E5 & $53.0 \pm 9.1$ \\
E24 & $37.3 \pm 8.7$ \\
E53 & $44.6 \pm 5.6$ \\
E53+P & $21.2 \pm 6.1$ \\
E72 & $6.7 \pm 4.1$ \\
E72 + P & $8.5 \pm 3.3$ \\
\hline
\end{tabular}
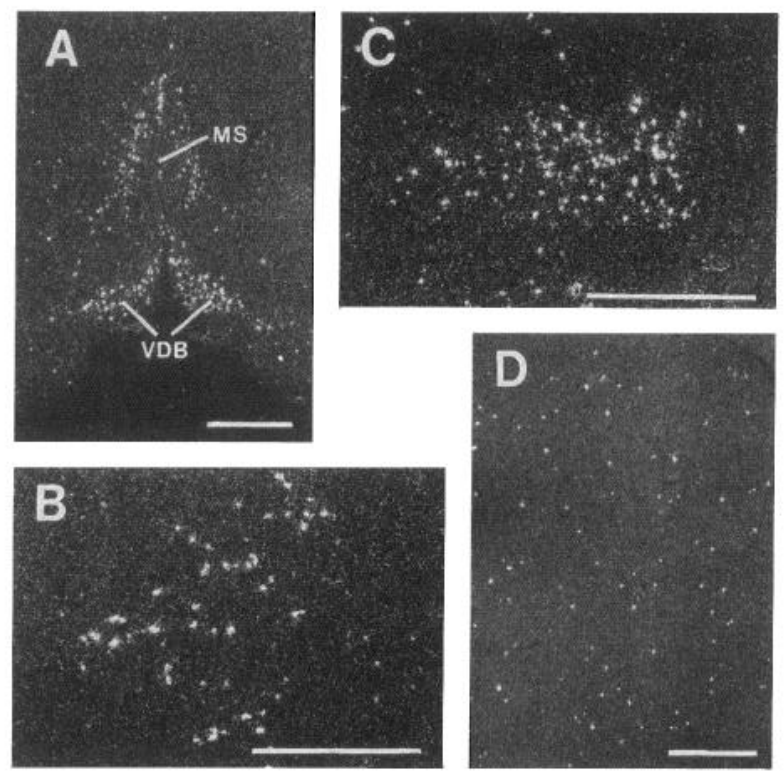

Figure 1. Dark-field photomicrographs showing the distribution of ChAT mRNA-containing cells detected in the MS $(A), \operatorname{NBM}(B), \mathrm{HDB}(C)$, and striatum $(D)$ of animals killed on diestrus 1 . Dorsal is toward the top. The hybridization signal consists of clusters of white silver grains overlying labeled cells. Note the distribution of labeled cells in the MS nucleus $(M S)$ and vertical limb of the DBB $(V D B)$. Note also the many labeled cells in the HDB and the NBM, as well as the presence of labeled cells scattered throughout the striatum. Scale bar, $1 \mathrm{~mm}$.

$\mathrm{pg} / \mathrm{ml}$ at $5 \mathrm{hr}, 37.3 \pm 8.7 \mathrm{pg} / \mathrm{ml}$ at $24 \mathrm{hr}, 44.6 \pm 5.6 \mathrm{pg} / \mathrm{ml}$ at $53 \mathrm{hr}$, and $<10 \mathrm{pg} / \mathrm{ml}$ at $72 \mathrm{hr}$ after injection.

Photomicrographs showing the distribution of ChAT mRNAcontaining cells detected in the MS, HDB, NBM, and striatum as seen under low-power, dark-field illumination are shown in Figure 1. Note the distribution of the labeled cells in each of the four regions analyzed. Examples of labeled cells as seen under higherpower, bright-field illumination are shown in Figure 2. Note the high numbers of silver grains overlying labeled cells compared with the low numbers of grains in surrounding regions. No labeled cells were detected in sections hybridized with the sense (control) probe or with buffer alone (not shown).

Relative cellular levels of ChAT mRNA in the MS, HDB, NBM, and striatum at different stages of the estrous cycle are summarized in Figure 3. Significant fluctuations in relative levels
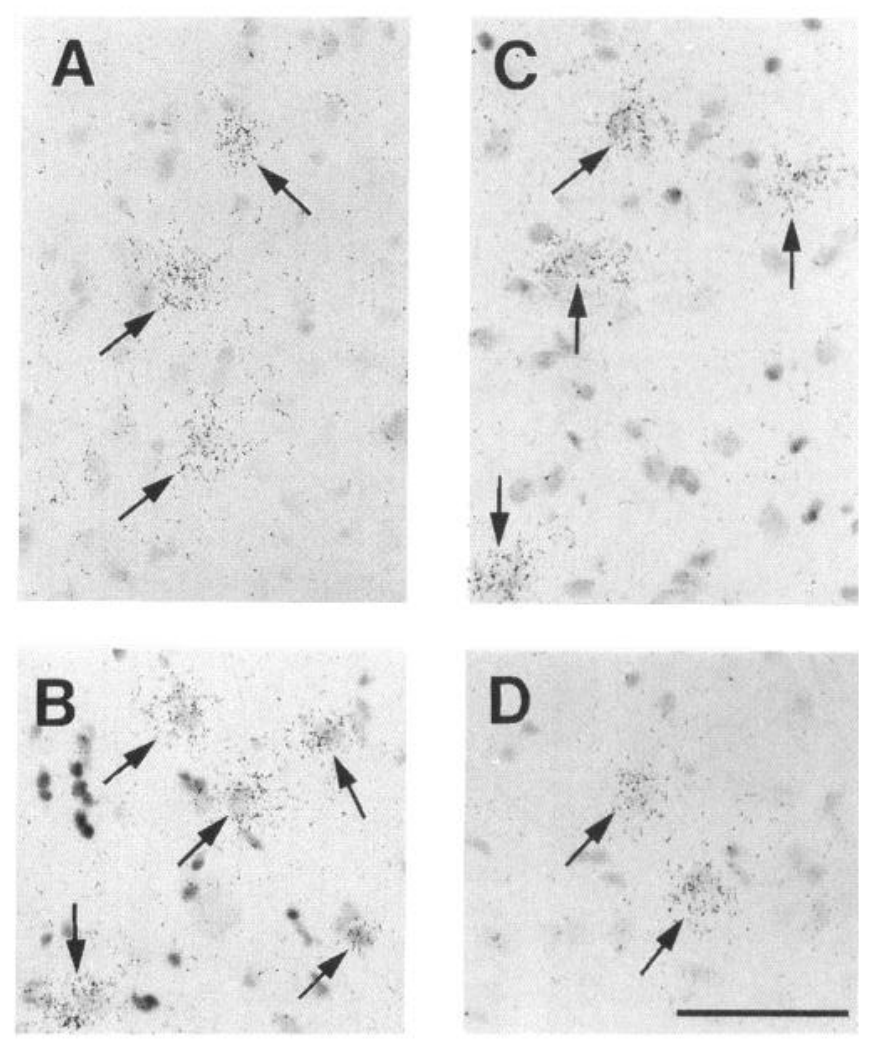

Figure 2. Bright-field photomicrographs showing examples of ChAT mRNA-containing cells detected in the MS $(A), \operatorname{NBM}(B), \mathrm{HDB}(C)$, and striatum $(D)$ of animals killed on diestrus 1 . The hybridization signal consists of clusters of dark silver grains overlying labeled cells (arrows) Note the large numbers of silver grains overlying labeled cells compared with the smaller numbers of grains overlying adjacent areas. Scale bar (shown in $D$ ), $100 \mu \mathrm{m}$ for all panels.

of ChAT mRNA were detected in the MS $(F=3.1, p=0.03)$ and the striatum $(F=3.5, p=0.02)$. The maximum percent fluctuation (peak-trough) during the estrous cycle was 24.6 and $26.9 \%$ in the MS and striatum, respectively. In both regions, the highest levels of ChAT mRNA were detected on diestrus 1. In the NBM, the maximum percent fluctuation in the relative levels of ChAT mRNA was $21.1 \%$, with the highest levels detected on diestrus 2; however, this difference was not statistically significant $(F=1.0, p$ $=0.41)$. In the HDB, relative levels of ChAT mRNA fluctuated a maximum of $11.1 \%$, which was not statistically significant $(F=$ $0.3, p=0.86)$.

The effects of hormone treatment on ChAT mRNA expression are summarized in Figure 4. Hormone treatments caused significant changes in relative cellular levels of ChAT mRNA in the MS $(F=3.9, p=0.01), \mathrm{NBM}(F=6.5, p<0.001)$, and striatum $(F$ $=4.6, p<0.01)$, but not in the HDB $(F=1.1, p=0.34)$. In the MS, a significant increase in ChAT mRNA was detected at $24 \mathrm{hr}$ $(22.0 \% \pm 2.0, p<0.01), 53 \mathrm{hr}(14.8 \% \pm 5.4, p=0.03)$, and $72 \mathrm{hr}$ $(15.1 \% \pm 6.0, p<0.03)$ after estrogen administration compared with ovariectomized controls. Subsequent administration of progesterone had no additional effect; differences between estrogentreated and estrogen plus progesterone-treated animals at 53 and $72 \mathrm{hr}$ were not statistically significant. In the NBM, a significant increase in ChAT mRNA was detected at $72 \mathrm{hr}(22.8 \% \pm 5.0, p$ $<0.01$ ) after estrogen administration. Administration of progesterone appeared to accelerate this effect such that animals that 
Figure 3. Relative levels of ChAT mRNA in the $M S$, $N B M, H D B$, and striatum (Str) in gonadally intact animals at different stages of the estrous cycle. Bars represent percent change from the arithmetic mean of the diestrus 2 animals \pm SEM. Note that significant fluctuations in relative levels of ChAT mRNA were detected in the MS and the striatum across the estrous cycle. ${ }^{*} p<0.05$.
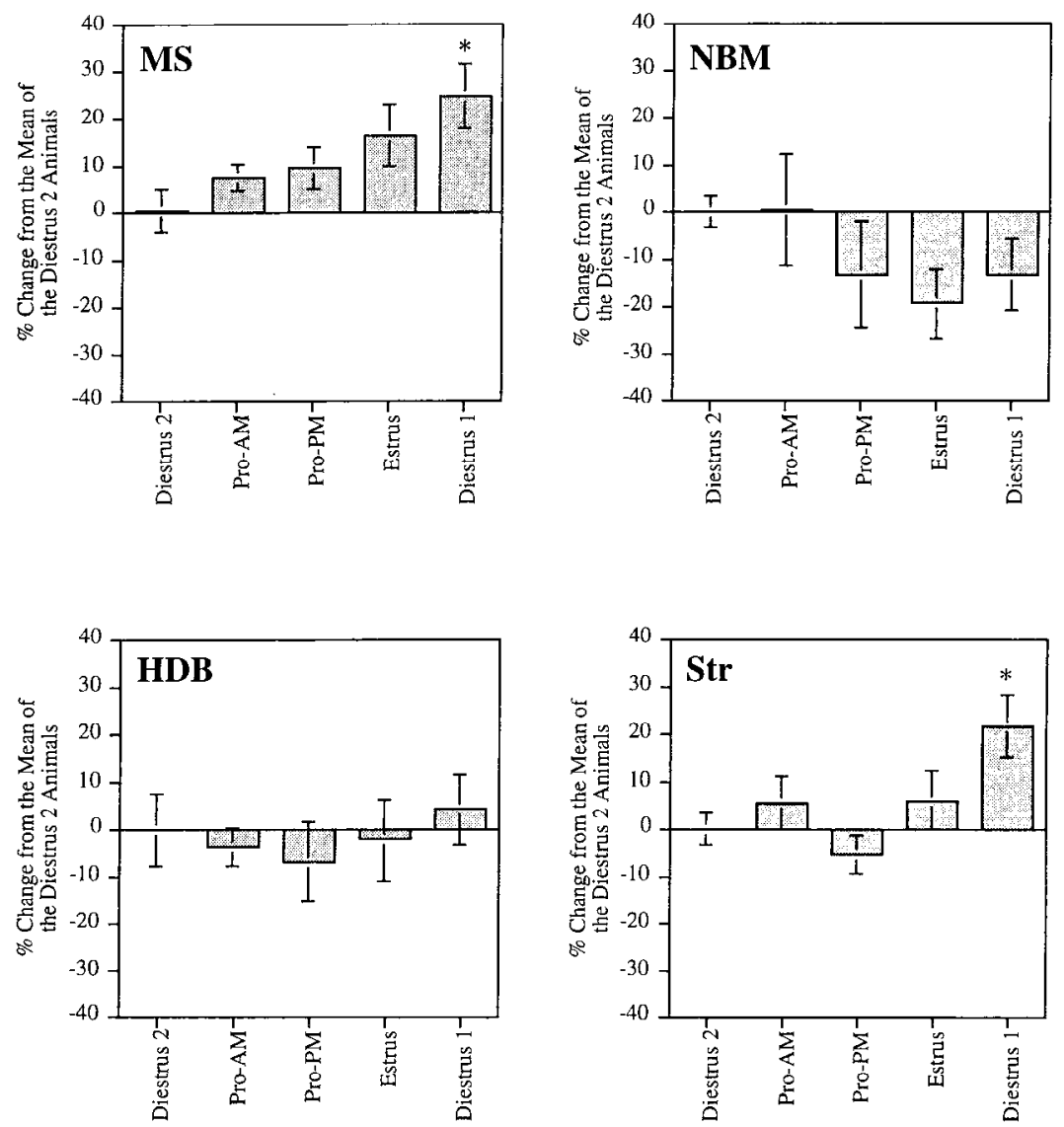

received progesterone $48 \mathrm{hr}$ after receiving estrogen showed significant clcvations in ChAT mRNA 5 hr later $(\mathrm{E} 53+\mathrm{P})$ compared with both ovariectomized controls $(27.9 \% \pm 3.1, p<0.01)$ and animals that had received estrogen alone $(\mathrm{E} 53 ; p=0.02)$. No significant difference was detected between estrogen-treated and estrogen plus progesterone-treated animals at $72 \mathrm{hr}$ after estrogen administration. In the striatum, a significant increase in ChAT mRNA was detected as early as $5 \mathrm{hr}$ after $(17.5 \% \pm 5.1, p<0.01)$ but not at 24,53 , or 72 hr after receiving estrogen alone. Significant increases were detected, however, at $5 \mathrm{hr}(\mathrm{E} 53+\mathrm{P} ; 20.4 \% \pm$ $2.3, p<0.01)$ and $24 \mathrm{hr}(\mathrm{E} 72+\mathrm{P} ; 15.9 \% \pm 3.5, p<0.01)$ after the subsequent administration of progesterone compared with ovariectomized controls.

\section{DISCUSSION}

The data demonstrate that levels of ChAT mRNA within discrete subregions of the basal forebrain fluctuate in accordance with physiological changes in the levels of estrogen and progesterone during the course of the estrous cycle and in response to acute hormone replacement. Of particular note are the following findings. (1) Estrogen administration had different effects on different subsets of basal forebrain cholinergic neurons (no effect in the HDB, a rapid but short-lived effect in the striatum, and delayed and longer-lasting effects in the MS and NBM). (2) Effects in some areas were preceded by a $2448 \mathrm{hr}$ delay and persisted even after estrogen levels had declined significantly. (3) Progesterone significantly enhanced the effects of estrogen at specific time points in some regions. For example, in the MS, significant upregulation $(22.0 \%$ ) of ChAT mRNA was detected at $24 \mathrm{hr}$, but not at $5 \mathrm{hr}$, after estrogen administration and then was maintained for an additional $48 \mathrm{hr}$ regardless of progesterone administration.
This was observed despite the fact that levels of circulating estradiol were highest at $5 \mathrm{hr}$ and had decreased significantly by $72 \mathrm{hr}$ after injection. In the NBM, significant upregulation $(22.8 \%)$ of ChAT mRNA was not detected until $72 \mathrm{hr}$ after estrogen administration, at a time when circulating levels of estrogen were significantly decreased. A comparable effect $(27.9 \%)$ was observed earlier, however, when progesterone was administered $48 \mathrm{hr}$ after estrogen treatment and the animals were processed $5 \mathrm{hr}$ later. The effect of estrogen plus progesterone then was maintained such that no difference between progesterone- and non-progesteronetreated animals was detected at $72 \mathrm{hr}$ after estrogen treatment. In the striatum, significant upregulation (17.5\%) of ChAT mRNA was detected as early as $5 \mathrm{hr}$ after estrogen administration but declined rapidly such that no significant effect was detected 24, 53, or 72 after receiving estrogen alone. A significant increase in ChAT mRNA was detected again $5 \mathrm{hr}(20.2 \%)$ and $24 \mathrm{hr}(15.9 \%)$ after the administration of progesterone, however, which suggests that progesterone can enhance and prolong the effects of estrogen on ChAT mRNA expression in the striatum. Note that these effects are consistent with previous reports showing significant increases in the numbers of ChAT-like immunoreactive cells in the MS and VDB (but not the IIDB), and significant increases in ChAT mRNA in the MS and NBM (but not the HDB), after longer-term continuous estrogen administration (Gibbs and Pfaff, 1992; Gibbs et al., 1994).

The effects of hormone replacement were consistent for the most part with the fluctuations in ChAT mRNA detected in each subregion of the basal forebrain during the course of the estrous cycle. For example, no significant fluctuation in the level of ChAT mRNA was detected in the HDB. In the MS, relative levels of 

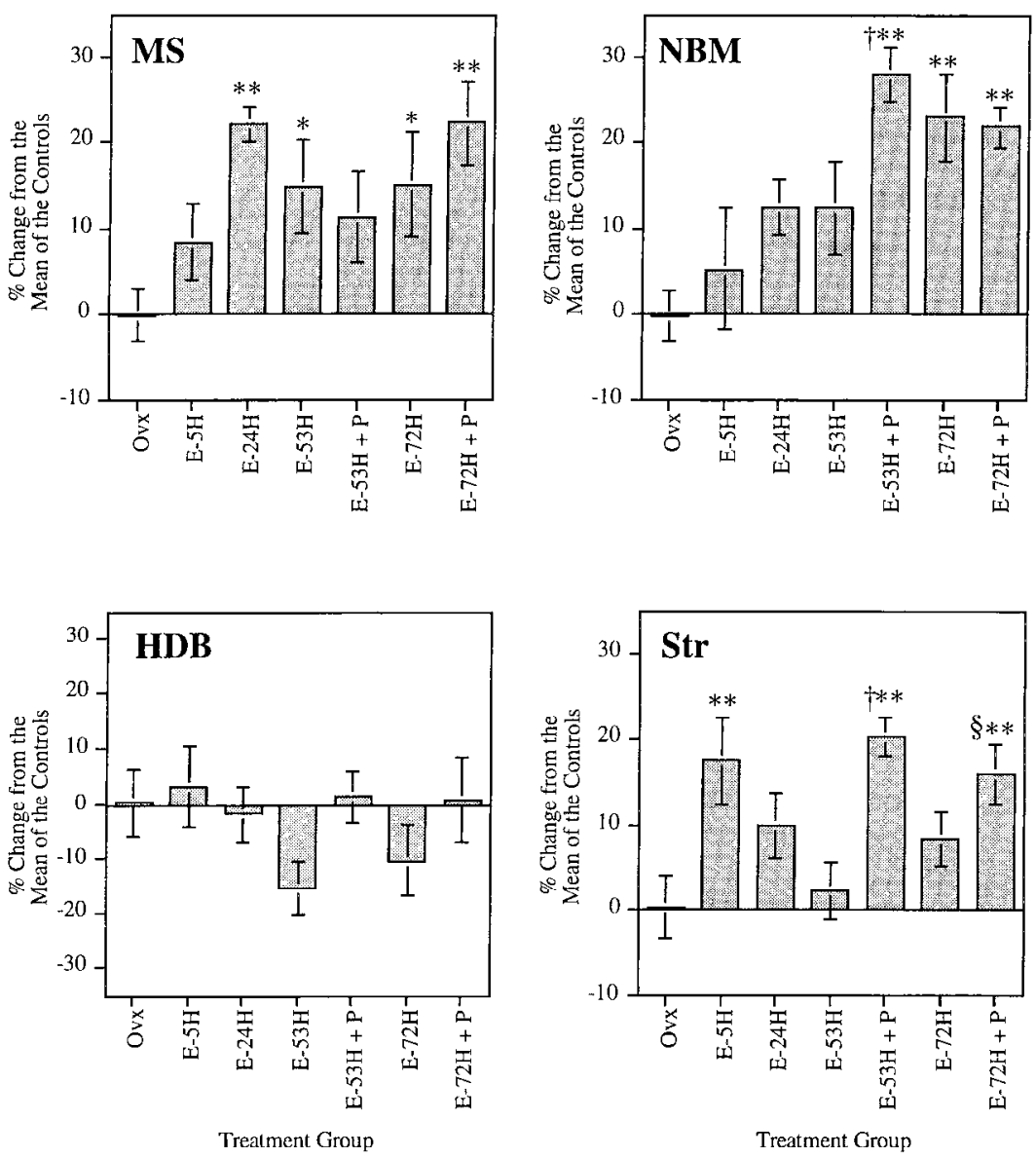

Figure 4. Effects of hormone treatment on relative levels of ChAT mRNA in the $M S, N B M, H D B$, and striatum (Str). Bars represent percent change from the arithmetic mean of the ovariectomized controls + SEM. Note the significant increases in ChAT mRNA detected after estrogen and/or estrogen plus progesterone administration in the MS, NBM, and striatum. ${ }^{*} p<0.05$ compared with ovariectomized controls; ${ }^{* *} p<0.01$ compared with ovariectomized controls; ${ }^{\dagger} p<0.05$ compared with $\mathrm{E} 53 ;{ }^{s} p<$ 0.05 compared with E72.
ChAT mRNA increased after proestrus and peaked on diestrus 1, nearly $2 \mathrm{~d}$ after peak levels of circulating estrogen. This is consistent with the $24 \mathrm{hr}$ delay between estrogen administration and changes in ChAT mRNA in the MS described above. Likewise, in the NBM the highest levels of ChAT mRNA were detected on diestrus 2, which is consistent with the $2-3 \mathrm{~d}$ delay between hormone administration and the changes in ChAT mRNA detected in the NBM. Although fluctuation in the NBM across the estrous cycle did not reach statistical significance, maximal fluctuation was $19.2 \%$, which is close to the changes of 22.8 and $21.8 \%$ detected $72 \mathrm{hr}$ after the administration of estrogen and estrogen plus progesterone. It is likely that the relatively long lag time of 3 $\mathrm{d}$ for the estrogen effect compounded by preparation for entry into another cycle added significant variation to the data, making fluctuations in the NBM of cycling aninals more difficult to detect. In the striatum, the highest levels of ChAT mRNA were detected on diestrus 1 , which is consistent with the effects of estrogen and progesterone administration on ChAT mRNA detected in the striatum.

Taken together, these data indicate that levels of ChAT mRNA in the MS, NBM, and striatum fluctuate significantly in response to changes in physiological levels of circulating gonadal steroids. Why a significant elevation in ChAT mRNA was not detected in the striatum on the morning of estrus is still unclear. One possibility is that rapid changes occur between the afternoon of proestrus and the morning of estrus at a time point not included in our sampling. Another possibility is that the cells are exposed to estrogen for a minimum length of time before a significant upregulation of ChAT mRNA by progesterone can be produced. This would be consistent with a need for estrogen-induced up- regulation of progesterone receptors in these cells before a progesterone effect is elicited. Whether basal forebrain cholinergic neurons express progesterone receptors and whether those receptors are regulated by physiological changes in circulating estrogen are still unclear. At least one previous study failed to detect basal or estrogen-induced progesterone receptors in the MS, DBB, and caudate-putamen (Parsons et al., 1982). Evidence for membranemediated effects of progesterone and progesterone metabolites have been described, particularly with respect to interactions with the $\mathrm{GABA}_{\mathrm{A}}$-receptor complex and $\mathrm{GABA}_{\mathrm{A}}$-mediated transmission (Robel and Baulieu, 1994). Local infusions of GABA or the $\mathrm{GABA}_{\mathrm{A}}$-receptor agonist muscimol produce significant reductions in the levels of $\mathrm{ACh}$ release in different areas of cortex (Wood and Richard, 1982; Casamenti et al., 1986). Selective impairments in memory performance after injections of muscimul into the NBM also have been described (Beninger et al., 1992). Clearly, the possibility that effects of progesterone on basal forebrain cholinergic neurons are related to effects on GABAergic transmission needs to be explored.

The mechanisms by which estrogen influences ChAT mRNA expression in basal forebrain cholinergic neurons remain unclear. Toran-Allerand et al. (1992) reported the presence of high-affinity estrogen-binding sites within NGF receptor-containing cells located in the MS and DBB. Likewise, we have recently detected the presence of estrogen receptor-like immunoreactivity within significant numbers of cholinergic neurons located in the MS, HDB, NBM, and striatum of gonadectomized rats (unpublished observations), providing a potential mechanism for direct estrogen effects on the cholinergic neurons. One possibility is that estrogen directly upregulates expression of the ChAT gene within specific 
cholinergic cells. This may be the case in the striatum, where a significant increase in ChAT mRNA was detected as early as $5 \mathrm{hr}$ after estrogen administration. Another possibility is that estrogen increases the half-life of ChAT mRNA inside the cell [comparable with the effects of estrogen on vitellogenin mRNA (Brock and Shapiro, 1983)], causing a gradual increase in ChAT mRNA over time. This could account for the rather long delay between estrogen administration and the effects on ChAT mRNA detected in the MS and NBM. It also could account for the fact that increases in ChAT mRNA in the MS and NBM persist well after estrogen levels have returned to baseline. Neither explanation fully accounts for the differences in the effects of estrogen and progesterone on cholinergic neurons located in different regions of the basal forebrain.

Other possibilities include indirect effects of estrogen mediated via other transmitter systems, growth factors, and growth-factor receptors that are known to influence basal forebrain cholinergic neurons directly. GABAergic and monoaminergic (noradrenalin and serotonin) effects on cholinergic neurons in the MS, DBB, and NBM have been described (for review, see Decker and McGaugh, 1991), and they may be influenced by estrogen administration. NGF and BDNF are present in the targets of cholinergic projection neurons, and both exert trophic effects on cholinergic neurons located in the MS, DBB, NBM, and striatum (Lapchak and Hefti, 1992; Morse et al., 1993; Emmett et al., 1995). NGF, in particular, upregulates ChAT mRNA, ChAT activity, high-affinity choline uptake, and $\mathrm{ACh}$ production and release within basal forebrain cholinergic neurons projecting to the hippocampal formation and cortex (for review, see Gibbs, 1994). The effects of the neurotrophins are mediated by binding to specific transmembrane receptors, including the low-affinity neurotrophin receptor (p75NGFR) and tyrosine kinase receptors specific for NGF (TrkA) and BDNF (TrkB) (Barbacid, 1993). Singh et al. (1995) reported significant elevations in hippocampal and cortical levels of BDNF mRNA after estrogen administration in rats. Effects of estrogen on relative levels of NGF mRNA also have been described, and both increases (Singh et al., 1993) and decreases (Gibbs et al., 1994) were reported. Gibbs and coworkers reported significant decreases in p75NGFR mRNA and protein (Gibbs and Pfaff, 1992) as well as decreases in TrkA mRNA (Gibbs ct al., 1994 ) in the MS and NBM after longer-term (2-6 weeks), continuous estrogen replacement. These data demonstrate that estrogen administration can have significant effects on growth factors and growth-factor receptors which, in turn, could influence ChAT expression within basal forebrain cholinergic neurons. Such an indirect mechanism could explain the rather long lag time between estrogen administration and effects on ChAT mRNA in the MS and NBM. It could also explain why no effects were detected in the HDB, as in previous reports (Gibbs and Pfaff, 1992; Gibbs et al., 1994), because cholinergic neurons in the HDB project primarily to the olfactory bulb, whereas those in the MS and NBM project primarily to the hippocampal formation and cortex. Whether similar effects occur in response to different dosages and regimens of estrogen treatment, and whether the effect that these changes have on the sensitivity of basal forebrain cholinergic neurons to specific growth factors, still needs to be determined.

In conclusion, these data indicate that physiological changes in circulating levels of estrogen can significantly affect relative levels of ChAT mRNA in the MS, NBM, and striatum of adult female rats. The data also indicate that subsequent administration of progesterone can significantly enhance the effects of estrogen on
$\mathrm{Ch} \Lambda \mathrm{T}$ mRN $\Lambda$ expression at specific time points. The extent to which these effects are mediated via direct hormone effects on basal forebrain cholinergic neurons needs to be assessed.

\section{REFERENCES}

Aigner TG, Mishkin M (1986) The effects of physostigmine and scopolamine on recognition memory in monkeys. Behav Neural Biol 45:81-87.

Barbacid M (1993) Nerve growth factor: a tale of two receptors. Oncogene 8:2033-2042.

Beninger RJ, Ingles JL, Mackenzie PJ, Jhamandas K, Boegman RJ (1992) Muscimol injections into the nucleus basalis magnocellularis of rats: selective impairment of working memory in the double Y-maze. Brain Res 597:66-73.

Beninger RJ, Wirsching BA, Jhamandas K, Boegman RJ (1989) Animal studies of brain acetylcholine and memory. Arch Gerontol Geriatr [Suppl] 1:71-89.

Brice A, Berrard S, Raynaud B, Ansieau S, Coppola T, Werber MJ, Mallet J (1989) Complete sequence of a cDNA encoding an active rat choline acetyltransferase: a tool to investigate the plasticity of cholinergic phenotype expression. J Neurosci Res 23:266-273.

Brock ML, Shapiro DJ (1983) Estrogen stabilizes vitellogenin mRNA against cytoplasmic degradation. Cell 34:207-214.

Casamenti F, Deffenu G, Abbamondi AL, Pepeu G (1986) Changes in cortical acetylcholine output induced by modulation of the nucleus basalis. Brain Res Bull 16:689-695.

Cox KH, DeLeon DV, Angerer LM, Angerer RC (1983) Detection of mRNA in sea urchin embryos by in situ hybridization using asymmetric RNA probes. Dev Biol 101:485-502.

Decker MW, McGaugh JL (1991) The role of interactions between the cholinergic system and other neuromodulatory systems in learning and memory. Synapse 7:151-168.

Dekker JAM, Connor DJ, Thal LJ (1991) The role of cholinergic projections from the nucleus basalis in memory. Neurosci Biobehav Rev 15:299-317.

Drachman DA (1977) Memory and cognitive function in man: does the cholinergic system have a specific role? Neurology 27:783-790.

Emmett CJ, Aswani SP, Stewart GR, Fairchild D, Johnson RM (1995) Dose-response comparison of recombinant human nerve growth factor and recombinant human basic fibroblast growth factor in the fimbria fornix model of acute cholinergic degeneration. Brain Res 673:199-207.

Gibbs RB (1994) Estrogen and nerve growth factor-related systems in brain: effects on basal forebrain cholinergic neurons and implications for learning and memory processes and aging. In: Hormonal restructuring of the adult brain: basic and clinical perspectives (Luine VN, Harding CF, eds), pp 165-199. New York: New York Academy of Science.

Gibbs RB, Pfaff DW (1992) Effects of estrogen and fimbria/fornix transection on $\mathrm{p} 75^{\mathrm{NGFR}}$ and ChAT expression in the medial septum and diagonal band of Broca. Exp Neurol 116:23-39.

Gibbs RB, Pfaff DW (1994) In situ hybridization detection of trkA mRNA in brain: distribution, co-localization with $\mathrm{p} 75^{\mathrm{NG} \text { (iFR }}$ and upregulation by nerve growth factor. J Comp Neurol 341:324-339.

Gibbs RB, Wu D-H, Hersh L, Pfaff DW (1994) Effects of estrogen on relative levels of ChAT, trkA, and NGF mRNAs in the rat forebrain and hippocampal formation. Exp Neurol 129:70-80.

Henderson VW, Paganini-Hill A, Emanuel CK, Dunn ME, Buckwalter JG (1994) Estrogen replacement therapy in older women: comparisons between Alzheimer's disease cases and nondemented control subjects. Arch Neurol 51:896-900.

Lapchak PA, Hefti F (1992) BDNF and NGF treatment in lesioned rats: effects on cholinergic function and weight gain. NeuroReport 3:405-408.

Luine VN (1985) Estradiol increases choline acetyltransferase activity in specific basal forebrain nuclei and projection areas of female rats. Exp Neurol 89:484-490.

Morse JK, Wiegand SJ, Anderson K, You Y, Cai N, Carnahan J, Miller J, DiStefano PS, Altar CA, Lindsay RM, Alderson RF (1993) Brainderived neurotrophic factor (BDNF) prevents the degeneration of medial septal cholinergic neurons following fimbria/fornix transection. J Neurosci 13:4146-4156.

Ohkura T, Isse K, Akazawa K, Hamamoto M, Yaoi Y, Hagino N (1994a) Evaluation of estrogen treatment in female patients with dementia of the Alzheimer type. Endocr J 41:361-371. 
Ohkura T, Isse K, Akazawa K, Hamamoto M, Yaoi Y, Hagino N (1991b) Low-dose estrogen replacement therapy for Alzheimer's disease in women. Menopause 1:125-130.

Ohkura T, Isse K, Akazawa K, Hamamolo M, Yaui Y, Hagino N (1995) Long-term estrogen replacement therapy in female patients with dementia of the Alzheimer type: 7 case reports. Dementia 6:99-107.

Parsons B, Rainbow TC, MacLusky NJ, McEwen BS (1982) Progestin receptor levels in rat hypothalamic and limbic nuclei. J Neurosci 2:1446-1452.

Paxinos G, Watson C (1986) The rat brain in stereotaxic atlas. London: Academic.

Penetar DM, McDonough JHJ (1983) Effects of cholinergic drugs on delayed matching-to-sample performance of rhesus monkeys. Pharmacol Biochem Behav 19:963-967.

Robel P, Baulieu E-E (1994) Neurosteroids: biosynthesis and function. Trends Endocrinol Metab 5:1-8.

Singh M, Meyer EM, Huang FS, Millard WJ, Simpkins JW (1993) Ovariectomy reduces ChAT activity and NGF mRNA levels in the frontal cortex and hippocampus of the female Sprague-Dawley rat. Soc Neu rosci Abstr 19:1254.
Singh M, Meyer EM, Millard WJ, Simpkins JW (1994) Ovarian steroid deprivation results in a reversible learning impairment and compromised cholinergic function in female Sprague-Dawley rats. Brain Res 644:305-312.

Singh M, Meyer EM, Simpkins JW (1995) The effects of ovariectomy and estradiol replacement on brain-derived neurotrophic factor messenger ribonucleic acid expression in cortical and hippocampal brain regions of female Sprague-Dawley rats. Endocrinology 136:2320-2324.

Toran-Allerand D, Miranda RC, Bentham WDL, Sohrabji F, Brown TJ, Hochberg RB, MacLusky NJ (1992) Estrogen receptors colocalize with low-affinity nerve growth factor receptors in cholinergic neurons of the basal forebrain. Proc Natl Acad Sci USA $89: 4668-4672$.

Uhl GR (1986) In situ hybridization in brain. New York: Plenum.

Wood PL, Richard J (1982) GABAergic regulation of the substantia innominata-cortical cholincrgic pathways. Ncuropharmacology 21:969-972 